\title{
A methodology to determine the potential of urban densification through roof stacking
}

\author{
Mohamed Amer ${ }^{\mathrm{a}, *}$, Ahmed Mustafa ${ }^{\mathrm{b}}$, Jacques Teller ${ }^{\mathrm{b}}$, Shady Attia ${ }^{\mathrm{a}}$, Sigrid Reiter ${ }^{\mathrm{b}}$ \\ a Sustainable Buildings Design Lab, Dept. UEE, Faculty of Applied Sciences, Université de Liège, Belgium \\ b Local Environment Management \& Analysis (LEMA), Dept. UEE, Faculty of Applied Sciences, Université de Liège, Belgium
}

\section{A R T I C L E I N F O}

\section{Keywords:}

Decision support

Workflow

Urban sprawl

Lightweight construction

Mapping

Brussels

\begin{abstract}
A B S T R A C T
Facing the need to accommodate a growing number of inhabitants in major European cities, this research aimed to establish a methodology that facilitates decision making on urban densification through roof stacking. The methodology adopts a systematic approach on three consecutive levels: urban, engineering, and social. Multiple criteria are identified to assess and map the roof stacking potential in terms of location and number of added floors. The Brussels Capital Region was chosen as a case study to experiment with the developed workflow chart and validate the proposed approach, using ArcGIS software, by creating a map of the urban densification potential through roof stacking of Brussels at the city scale. The results show a realistic potential of accommodating $30 \%$ of the expected population increase in Brussels by the year 2040 using only roof stacking, provided that the current urban regulations are respected. In addition, a theoretical potential to accommodate more than the expected population increase by the same year is proposed provided that urban planning regulations are relaxed in relation to the height of buildings. Further applications to other cities in Europe would help create additional opportunities to develop an automated tool for estimating such potentials on a wider scope.
\end{abstract}

\section{Introduction}

Due to population and economic growth, globalisation and European integration, and land price and inner city problems, rapid urbanisation and urban sprawl phenomena have occurred (EEA, 2006; Vasili, 2013). This has resulted in an increasingly large urban footprint and higher levels of $\mathrm{CO}_{2}$ emissions. New urban agendas have promoted the development of urban spatial frameworks. These frameworks adopt an approach toward sustainable land use management based on appropriate compactness, polycentrism, and mixed use through infill development or planned extension strategies, which prevents urban sprawl and marginalisation (United Nations, 2017). Accordingly, multiple approaches are followed to achieve compactness and urban densification, such as infill development and roof extensions.

This paper provides a model for decision support to optimise urban densification through roof stacking, based on a triple analysis of the built environment at the urban planning, engineering, and architectural levels. In this paper, a methodology is developed to assess at different urban scales the primary potential for urban densification by providing more dwellings through roof stacking. It sets criteria to measure and map that potential in terms of location and added floors, providing guidance to urban planners and decision-makers establishing development programs based on quantified results and values. The significance of this research lies in the creation of a generic approach that relies on available information from a GIS database to evaluate and quantify the urban roof stacking potential and that further assists in the creation of maps that identify such characteristics and represent the location of that potential. This paper presents an integrative approach for decision making pertaining to urban densification through roof stacking, by which each of the urban, engineering, and architectural aspects is taken into consideration and illustrated in one workflow chart.

A review of the literature critically covers the evidence behind the choice of accommodating the growing population of Europe by densifying its major cities or by extending urban sprawl. Consequently, a method for reaching a reasonable urban densification through roof stacking is proposed as a sustainable approach toward housing an increasing population with minimum effects on the environment, while also taking into account the quality of life in cities. To define this potential for roof stacking, a set of criteria was identified and a workflow chart that illustrates the entire methodology and acts as a tool for decision making was developed. Using the city of Brussels as a case study, various maps were generated to visualise the densification potential. This research targets policy and decision makers at the regional and

\footnotetext{
* Corresponding author.

E-mail address: mohamed.amer@ulg.ac.be (M. Amer).
} 
district levels, as well as real estate developers and urban planners. The framework presented aids the decision making process for using roof stacking as an approach toward developing sustainable urban densification and optimal city compactness.

This paper is organised into seven main sections. The first section introduces the research. The second section reviews the expected increase in the population of Europe, urban sprawl and its consequences on the environment, and regional strategies for urban containment, in addition to urban densification methods at the city scale and their advantages and disadvantages. The third section introduces the methodology established by this research, a workflow chart illustration, and mapping criteria for urban densification through roof stacking. The fourth section focuses on the application of the methodology in a case study, by which maps of urban densification potential in the city of Brussels are generated using the developed workflow chart. The fifth section presents and analyses the final maps and the results of this application to the Brussels Capital Region. The sixth section presents a summary of the main findings of this research and discusses the further usage, strengths, and limitations of the developed tool. The last section presents the conclusions of the paper.

\section{Literature review}

\subsection{Increasing population in Europe}

Worldwide, population is expected to increase by $32 \%$ by the year 2050 , which is equivalent to an increase of 2.37 billion inhabitants. Even though the fertility rate is lower in Europe than on other continents, Europe is affected by the global increase of population and migration dynamics (United Nations, 2015). According to the Intentional Migration, Integration and Social Cohesion (IMISCOE) network, it has been reported that an emergence in the global migration market was evident in the last two decades (Bonifazi, Okólski, Schoorl, \& Simon, 2008; OECD, 2001). When European countries are grouped according to income rather than geography, countries with higher income receive an average of 4.1 million immigrants annually from lower income EU and non-EU countries. It is expected that the total net gain of immigrants in high income countries will reach 91 million by 2050 (United Nations, 2015). This migration has multiple consequences for urban configurations and housing policies. It has been observed that immigrants, seeking the financial and social opportunities offered by large cities, settle mostly in urbanised areas (EEA, 2006).

\subsection{Urban sprawl and containment strategies}

As a result of population and economic growth, globalisation and European integration, and land price and inner city problems, an urban sprawl phenomenon has developed (Vasili, 2013). Marshall (2007) reported that urban growth increases with a frequency equivalent to and sometimes higher than population growth rate. At present, $75 \%$ of the European population lives in urban areas, and the urban population is expected to increase to $80 \%$ by 2020 ; however, seven European countries will have $90 \%$ of their population living in urban areas by 2020 , but a large portion of these areas are sprawled. The major secondary effects of unplanned urban sprawl are increasing consumption of energy in both the building and transportation sectors (Steemers, 2003), loss of land and soil (Attia \& De Herde, 2010; EEA, 2006), which threatens the natural and rural environment of Europe and contributes to the loss of farmland, increases in carbon emissions and effects on the local climate of the region (Angel, Parent, Civco, \& Blei, n.d.; Seto, Fragkias, Güneralp, \& Reilly, 2011), and numerous other problems, such as diminishment of soil infiltration, dependency on cars, and increasing costs of infrastructure, networks, and services (Marique, Dujardin, Teller, \& Reiter, 2013). Even if some effects related to high compactness, such as congestion, air pollution, increases of land prices, and others, are problematic and low-density developments are one of the preferred living accommodations (Gordon \& Richardson, 1997; Howley, 2009), the negative environmental and economic consequences of urban sprawl prevail. Several governments in Europe have attempted to limit urban sprawl through manifold integrated urban growth management strategies, bringing together municipalities, civil society, business, and economy. At the urban planning level, Pendall, Martin, and Fulton (2002) classified urban containment strategies into three major types: green belts, urban growth boundaries (UGB), and urban service boundaries.

The first type of urban containment strategy, the green belt, is defined as continuous green physical space that surrounds metropolitan regions and urbanised areas (Gennaio, Hersperger, \& Bürgi, 2009). The goals of establishing green belts are to prevent neighbouring towns from merging with each other, check unrestricted sprawl, safeguard countryside from encroachment, preserve the special character of historic towns, and assist urban generation (Presland, 2016). In Germany, approximately $60 \%$ of the planning regions have implemented green belt strategies in their development plants (Seto, Fragkias, Güneralp, \& Reilly, 2016). In England, around 13\% of the land is designated as green belt (Presland, 2016). However, as green belts are initially intended to conserve the biodiversity of the landscapes, one crucial performance criterion for green belts to ensure successful urban containment is belt tightness and the amount of land remaining for further development in the expansion area between the boundary and the belt (Siedentop et al., 2016). A tight green belt can result in negative consequences, the most widely mentioned of which is known as "leapfrogging", which is characterised by the formation of satellite neighbourhoods around the green belt leading to undesirable impacts on the countryside (Westerink et al., 2012). The second type of urban containment strategy is the urban growth boundary (UGB), which is defined as a regulatory line that separates and divides urban and rural areas. The area within the boundary is intended for urban use, whereas the area outside of the boundary is intended for rural use. Zoning is used as a tool for defining and implementing the UGB (Vasili, 2013). The UGB boundary may also be reassessed and extended based on current need to accommodate additional population (Bengston \& Youn, 2006). The third type of urban containment policy is the urban service boundary, which is more flexible than the UGB. An urban service boundary determines the boundary beyond which urban infrastructure is not supplied. However, in principle, this does not prohibit the expansion of developed area beyond the service boundary zone (Dearborn \& Gygi, 1993; Poradek, 1997).

In conclusion, each of the urban containment strategies has its own drawbacks, which usually necessitates a wider framework at the regional and urban level to work simultaneously on urban densification and containment strategies to ensure best practises. Reasonable urban densification is a recommended and valid framework to limit urban sprawl and support containment strategies at the spatial, economic, and infrastructure levels.

\subsection{Urban densification methods}

Urban densification refers to the approach of compact city planning, which has been progressively argued since the 1990s and has been considered widely as a global applied planning concept (de Roo, 2000; Jenks \& Colin, 2010). Three main characteristics define a compact city: dense and proximate development patterns, urban areas linked by transportation, and accessibility to local services (OECD, 2012). Boyko and Cooper (2011) have explored definitions of densification and methods of measuring the density of cities. They propose an extensive comparison between densification and sprawl approaches in terms of mobility, land use, social equity, green spaces, energy, and their physical advantages and disadvantages. Other research has worked on the question: "where should densification occur?" Marique and Reiter (2014a)) claimed that the increase in density of existing 
neighbourhoods should be focused on the areas that are the best located and equipped with urban services. Densification along public transportation nodes encourages inhabitants to use fewer private vehicles for commuting and thus reduces carbon emissions in cities (Schmitt \& Reardon, 2012). In some cases, densification is a solution with higher urgency due to inevitable pressures such as geographical or geo-political constraints.

Moving toward urban densification intends to provide a solution for accommodating a population increase in major cities or suburbs, while also counteracting sprawl outside of the city and encroachment on farmland and green areas. Densification strategies are usually included in the planning policies of many European cities, with the goal of approaching sustainable urban development. However, densification may inherit several problems in land use policies as a consequence of the deviation between theory and practice (Davison, 1995; Knight, 1995; Williams, 1999). More precisely, many contradictions may occur at different levels, such as the political, planning, and socioeconomic levels (Breheny, 1992, 1997; Williams, Burton, \& Jenks, 1996). Urban densification presents several risks, including increasing air pollution and congestion, modifying the urban morphology and architectural typologies, neglecting urban heritage, creating heat islands and wind discomfort (Reiter, 2010), reducing daylighting and solar access (Marique \& Reiter, 2014b), putting pressure on urban infrastructure, networks, and services, among others. Moreover, several researchers have debated the correlation between high urban density and reduced use of automobiles (Williams, 1997).

Some research has highlighted the secondary effects of some types of densification on urban green areas (Byomkesh, Nakagoshi, \& Dewan, 2012; Rafiee, Salman Mahiny, \& Khorasani, 2009; van Heezik \& Adams, 2014), with the goal of defining challenges to and strategies for flourishing urban green spaces (Bolleter \& Ramalho, 2014; Haaland \& van den Bosch, 2015).

Several methods of urban densification have been implemented. The first method is densification by filling the "backyards" of existing buildings, thus creating a horizontal extension (Marique \& Reiter, 2014a). The second method, referred to as infill development, is the process of closing the gaps and vacant lots between buildings in the city (Marique \& Reiter, 2014a). A good example is the initiative made by the city of Cologne, called "Baulückenprogramm", by which 20,000 new dwellings were built by infill development (Attenberger, 2014; Stadt Köln, 2011). The third method of densification is demolishing existing low-density buildings and replacing them with higher-density structures, for example high-rise buildings or compact-frame structures (Attia, 2015; Burton, Jenks, \& Williams, 2013; Marique \& Reiter, 2014a).

A fourth method of densification is transforming and renovating saddle roofs on the top of buildings into wider and liveable spaces (Floerke, Weiß, Stein, \& Wagner, 2014; Tichelmann \& Groß, 2016). This method has the double benefit of making use of the negligible zone of the attic and helping to reduce the total energy consumption of the building by enhancing the quality of the roof and the building's insulation. A fifth method is densification through roof stacking, which is the method of concern in this research (Amer \& Attia, 2017; Attia, 2015). Roof stacking is simply the addition of stories to existing buildings to accommodate more inhabitants. The capacity for and number of added stories depends on several factors that will be discussed briefly in the following sections. Table 2 provides a summary and comparison of the various densification methods.

A part of the responsibility of local authorities is to define the densification need capacity and form (Burton,Williams, \& Jenks, 1996; Williams, 1997, 1998) based on the characteristics of each city (geology, climate, urban morphology, types of buildings, mobility behaviours, transportation networks, etc.), while avoiding densities that are too high or too low and respecting both sustainable development and the quality of urban life.

As shown in Table 1, similar to the case for urban containment strategies, each method of urban densification has its benefits and drawbacks. Additionally, there are numerous cases of best practises for each type of urban densification strategy. The roof stacking strategy was selected in this work because it maintains the actual potential for urban green spaces, recreational areas, and urban services, while offering an opportunity to reduce the cost efficiency of energy consumption of a large number of existing buildings as a result of the roof stacking, which is a very important issue for the energy management of cities (Reiter \& Marique, 2012). Although, in many cases, urban densification at the scale of the city will be achieved by combining the five aforementioned strategies, this paper focuses only on the roof stacking strategy and ways to avoid its disadvantages.

\section{Methodology}

There is currently a lack of tools to help city authorities plan a reasonable densification of urban areas that respects both sustainable development and quality of urban life. In this research, a methodology was developed to identify the potential for urban densification through only the roof stacking method. This research aimed to provide a model to aid decision support for increasing urban density by roof stacking at the city, suburb, or neighbourhood scales. The objective of the research was to develop a methodology for identifying the primary potential for urban densification by providing additional dwellings through roof stacking. According to this methodology, a map of the Brussels Capital Region was produced as a fast-track measurement approach to identify quantitatively the capacity to accommodate additional population only by providing additional dwellings on the roof tops of existing buildings in already urbanised areas.

The methodology developed in this paper aims to provide a generic approach for decision making pertaining to the roof stacking potential in European cities. Based on a literature review, a workflow chart is developed to explain the entire decision-making process for roof stacking. The workflow consists of three main phases, and each phase is explained in detail below. Then, the two first phases are validated based by an appropriate case study using the Brussels Capital Region. Criteria for mapping the urban densification potential by roof stacking are established and the roof stacking potential is identified based on urban regulations and limited structural information of the buildings using ArcGIS software and the information available in the Brussels GIS database. The presentation of the case study is followed by discussion and criticism debating the generalisation potential of the applied methodology at the scale of Europe and highlighting the limitations and potential development of the methodology to increase its robustness. The following sections describe the steps undertaken in detail.

\subsection{The workflow chart}

The workflow chart is a methodology that is applicable at different urban scales, such as the scale of a city, town, suburb, or specific neighbourhood. The proposed workflow chart, as shown in Fig. 1, is divided into three main consecutive phases of decision making. The first phase focuses on the urban and policies configurations of the selected urban cadastre. An urban cadastre includes the geometric description of land parcels with up-to-date land information. The second phase focuses on the generic structural configurations of the urban cadastre. The third and last phase focuses on the detailed architectural and structural configurations of each separate building and acquiring the owner's approval. On the basis of theory, the methodology provides the theoretical foundation for implementation of roof stacking at the urban level, while in practice, it is intended to represent a systematic approach for urban planners and decision makers at the municipal level. Thus, it represents a top-bottom approach on a strategic level for determining and estimating the potential of any city to accommodate increasing population by the means of roof stacking, while taking into consideration the different stakeholders at every level of the decision 
Table 1

Analysis of urban containment strategies.

\begin{tabular}{|c|c|c|c|}
\hline Strategy & Characteristics & Benefits & Drawbacks \\
\hline \multirow[t]{3}{*}{ Greenbelt } & $\begin{array}{l}\text { Physical space surrounds the urban area to limit } \\
\text { sprawl and conserve green spaces }\end{array}$ & - Fixed area & - Tendency for leapfrogging \\
\hline & & - Conserves green spaces & $\begin{array}{l}\text { - Attractive area for real estate } \\
\text { developers }\end{array}$ \\
\hline & & - Better environmental qualities & \\
\hline $\begin{array}{l}\text { Urban Growth Boundary } \\
\text { (UGB) }\end{array}$ & $\begin{array}{l}\text { Regulatory line separating city urbanized area and } \\
\text { rural area }\end{array}$ & $\begin{array}{l}\text { Defined by policy makers according to city } \\
\text { needs }\end{array}$ & - Unfixed line that can expand \\
\hline Urban Service boundary & $\begin{array}{l}\text { Regulatory line that defines the maximum urban } \\
\text { infrastructure supply }\end{array}$ & $\begin{array}{l}\text { - Limits costs paid for new infrastructure by } \\
\text { the government }\end{array}$ & $\begin{array}{l}\text { - Does not limit or regulate urban } \\
\text { sprawl }\end{array}$ \\
\hline
\end{tabular}

making process. One of the main objectives of the proposed workflow is to overcome the deviation in urban densification that has resulted from single-issue research approaches (Breheny, 1992; Williams et al., 1996). The following sections describe each phase in detail.

\subsubsection{First phase: urban and policies configurations}

The first phase of the workflow chart investigates the primary need and potential for densification though increasing the vertical heights of residential buildings according to the policies and regulations provided by the concerned municipality or city. These issues are decided and implemented by urban planners and decision makers at the municipal level. First, the need for densification is based on various reasons, such as the expected increase in population in a certain area, adhering to the urban agenda for compact cities, or even on individual requests to raise a rooftop. Second, some buildings will be listed as heritage buildings with either restrictions or prohibitions for modification. Once a building is listed as a heritage structure, minimal intervention or no intervention at all can take place. Then, the policies and regulations that allow roof stacking and an increase of buildings heights are reviewed by policy makers, who consider the maximum height, urban daylighting requirements, and accessibility to transportation networks and parking plots.

At this level of analysis, two principal pieces of information are defined: first, the demand for and applicability of densification through roof stacking, and second, the maximum height that can be achieved based on the urban configurations.

\subsubsection{Second phase: engineering configurations}

In the second phase, the proposed decision making workflow utilises additional information provided by the GIS database to determine the potential and capacity for roof stacking at the building block level. Structural configurations of the buildings may be identified from existing data in the GIS database of the city. However, in this research, the structure and foundation type were identified based on the year of construction and the corresponding building prototypes in Brussels due to limitations in the available data. Based on the structural analysis of the existing buildings, soil, actual height, estimated additional weight per square meter, and the potential for roof stacking can be identified.

It is important to mention that the first two phases aim to provide only a fast-track measurement of the potential increase of the number of stories for each building. The uncertainty of the final results is inversely proportional with the available data used in the first two phases. The more data attained at the urban and structural level, the more accurate the results can be.

\subsubsection{Third phase: architectural configurations}

The third and last phase is focusing on the detailed assessment of the blocks having potential for roof stacking. At this level, the participation of each of the architects, engineers, and homeowners takes place with direct coordination with the municipality. It represents the grass-roots level of decision making for roof stacking configuration at the building level. Given that the first two phases provide only approximate guidance, the third phase aims to provide actual and precise measurements. Once primary approval is achieved in the third level, detailed analyses on the architectural and structural scale are undertaken. At the structural level, detailed structural analysis should be done to calculate the actual strength of the existing structures. According to the ISO 13822 (ISO 13822, 2010), a statement of principles and procedures is provided to assess the structures of the existing buildings. Based on several factors, the type of tests, which may range from non-destructive testing methods (NDT) to destructive testing methods (DT), are identified (Runkiewicz, 2009).

Based on the strength of the actual buildings, precise estimations for the number of floors that can be added can be provided. While on the architectural level, existing architectural plans are acquired and new plans with the added stories are proposed, along with further calculations for the sewage and sanitation capacities and feasibility studies. Based on the results of the analysis, a second and final approval can be undertaken based on the feasibility studies made for the project. Accordingly, the implementation phase begins to take place.

\section{Case study}

Because this research is concerned with the potential for roof stacking specifically in the context of Europe, the Brussels Capital Region, as the capital of Belgium and the European Union, was chosen as a case study to validate the workflow and the methodology developed in this research. Among the cities in Belgium, Brussels has the fastest growing population, with an expected 190,000 additional inhabitants by 2040 , and the additional challenge of the entire regional territory being fully urbanised (Deboosere, 2010; Paryski \& Pankratieva, 2012). The reason behind the city's population growth dates back to the 1990s as a result of two main phenomena. The first is an increase in the rate of international migration, prompted by individuals seeking better employment opportunities, and the second is the reinvigoration of birth rate. The population of Brussels increased by 225,000 inhabitants in just the 20 years preceding 2015 (an average of 11,250 people per year) to 1.100 million at the beginning of this year. Over the same period, the number of households increased by 75,500 units, with an average of 3800 units per year (Dessouroux et al., 2016). Thus, the change resulted in an average population density of the region of slightly more than 66 inhabitants/ha (including non-constructible areas, 2010 data). However, this density varies greatly from one neighbourhood to another. In 2010, the densest neighbourhood had 362.43 inhabitants/ha, while the least densely populated area had only 2.64 inhabitants/ha, which provides additional space to accommodate increasing population without loss of urban quality. The dominant socioeconomic groups living in the central part of Brussels are the middleand low-income groups; the higher income groups live outside the city's centre (Dessouroux et al., 2016).

As a consequence of the increase in the population of Brussels, the government has implemented several infill developments and housing projects. Approximately 5000 housing units are being produced annually in Brussels. These housing units are divided into three main 
Table 2

Analysis of urban densification strategies.

\begin{tabular}{|c|c|c|c|}
\hline Method & Characterization & Advantages & Disadvantages \\
\hline \multirow[t]{4}{*}{ Filling Backyards } & $\begin{array}{l}\text { Creating horizontal extension, increasing the surface } \\
\text { area of existing buildings on their backyards (Attia, } \\
\text { 2015; Marique \& Reiter, 2014a) }\end{array}$ & $\begin{array}{l}\text { - Provide additional space for the } \\
\text { same property }\end{array}$ & - Seal more surface \\
\hline & & $\begin{array}{l}\text { - Opportunity to improve the } \\
\text { density while preserving the } \\
\text { urban landscape }\end{array}$ & - Increasing carbon footprint \\
\hline & & $\begin{array}{l}\text { - Retains the integrity of existing } \\
\text { dwellings }\end{array}$ & - Reduce vegetation surfaces \\
\hline & & & $\begin{array}{l}\text { - Increase heat island effects } \\
\text { - Needs to adapt transportation infrastructure and } \\
\text { mobility strategies } \\
\text { - Needs to increase urban services }\end{array}$ \\
\hline \multirow[t]{5}{*}{ Infill } & $\begin{array}{l}\text { Establishing new buildings on vacant lots and gaps } \\
\text { between buildings or areas not built-up previously or } \\
\text { built-up areas with other purposes (Brunner \& Cozens, } \\
\text { 2013; Marique \& Reiter,2014) }\end{array}$ & $\begin{array}{l}\text { - Usage of abandoned areas and } \\
\text { opportunity of revitalizing these } \\
\text { spaces }\end{array}$ & $\begin{array}{l}\text { - Occupy spaces with a vegetation or recreational } \\
\text { function potential }\end{array}$ \\
\hline & & - Usage of existing infrastructure & $\begin{array}{l}\text { Occupy spaces with parking or collective service } \\
\text { potential }\end{array}$ \\
\hline & & $\begin{array}{l}\text { Opportunity to improve the } \\
\text { density while preserving the } \\
\text { urban landscape and urban } \\
\text { morphology }\end{array}$ & - Needs to adapt mobility strategies \\
\hline & & $\begin{array}{l}\text { - Retains the integrity of existing } \\
\text { dwellings }\end{array}$ & - Needs to increase urban services \\
\hline & & & $\begin{array}{l}\text { - Potential damage to the nearby buildings during } \\
\text { construction process. }\end{array}$ \\
\hline \multirow[t]{3}{*}{ Demolish \& rebuild } & $\begin{array}{l}\text { Applied in areas with lower density where houses are } \\
\text { demolished and replaced with high-rise buildings or } \\
\text { compact frame (Burton et al., 2013; Marique \& Reiter, } \\
\text { 2014a) }\end{array}$ & $\begin{array}{l}\text { Higher flexibility to increasing } \\
\text { density on any certain plot }\end{array}$ & - Critical in already high dense neighbourhood \\
\hline & & $\begin{array}{l}\text { Opportunity to apply designs } \\
\text { with higher efficiency }\end{array}$ & - Increases the use of materials and construction waste \\
\hline & & & $\begin{array}{l}\text { - High cost is accompanied by demolition and new } \\
\text { construction } \\
\text { - Loss of resources (existing infrastructure, etc.) } \\
\text { - Risk for the urban heritage } \\
\text { - Transformation of the city skyline and urban } \\
\text { morphology } \\
\text { - Needs to adapt mobility strategies } \\
\text { - Needs to increase urban services }\end{array}$ \\
\hline \multirow[t]{5}{*}{ Roof transformation } & $\begin{array}{l}\text { Transformation of saddle roofs into a complete storey } \\
\text { with flat roof and larger floor area (Tichelmann \& Groß, } \\
\text { 2016) }\end{array}$ & $\begin{array}{l}\text { Does not occupy additional } \\
\text { urban spaces and does not } \\
\text { increase soil waterproofing }\end{array}$ & - Limited opportunity to increase density \\
\hline & & $\begin{array}{l}\text { - Requires a minimal cost } \\
\text { compared to other methods }\end{array}$ & - Transformation of the city skyline \\
\hline & & $\begin{array}{l}\text { Easy and quick solution for } \\
\text { already urbanized districts }\end{array}$ & - Limitation for heritage buildings \\
\hline & & - Usage of existing infrastructure & - Needs to adapt mobility strategies \\
\hline & & $\begin{array}{l}\text { Opportunity to reduce energy } \\
\text { consumption of existing } \\
\text { buildings through roof insulation }\end{array}$ & - Needs to increase urban services \\
\hline \multirow[t]{6}{*}{ Roof stacking } & $\begin{array}{l}\text { Added structure over the rooftop of an existing building } \\
\text { to create one or more stories of living spaces } \\
\text { (Amer \& Attia, 2017; Floerke et al., 2014; Nilsson, } \\
\text { Blomsterberg, \& Landin, 2016; Peronato, 2014) }\end{array}$ & $\begin{array}{l}\text { Does not occupy additional } \\
\text { urban spaces and does not } \\
\text { increase soil waterproofing }\end{array}$ & $\begin{array}{l}\text { - Increases services loads on existing buildings and } \\
\text { requires verification with actual strength of the } \\
\text { building and foundation }\end{array}$ \\
\hline & & $\begin{array}{l}\text { Keep the actual potential for } \\
\text { green spaces, recreational } \\
\text { function or urban services }\end{array}$ & $\begin{array}{l}\text { - Transformation of the city skyline and urban } \\
\text { morphology, with potential negative impact on the } \\
\text { urban microclimate (e.g. wind } \\
\text { tunnels \& overshadowing) }\end{array}$ \\
\hline & & $\begin{array}{l}\text { Easily applicable in already } \\
\text { urbanized districts }\end{array}$ & $\begin{array}{l}\text { Risk of daylighting and solar access reductions for } \\
\text { the neighbours }\end{array}$ \\
\hline & & $\begin{array}{l}\text { Usage of existing infrastructure } \\
\text { Opportunity to reduce cost- } \\
\text { efficiently energy consumption } \\
\text { of existing buildings (Attia, } \\
\text { 2017; Attia, 2016) }\end{array}$ & $\begin{array}{l}\text { - Limitation for heritage buildings } \\
\text { - Needs to adapt mobility strategies }\end{array}$ \\
\hline & & $\begin{array}{l}\text { increases the value of the } \\
\text { existing property and creates a } \\
\text { financial revenue (Amer \& Attia } \\
\text { 2017) }\end{array}$ & - Needs to increase urban services \\
\hline & & & $\begin{array}{l}\text { - Potential of creating noise and dust during the } \\
\text { construction process }\end{array}$ \\
\hline
\end{tabular}




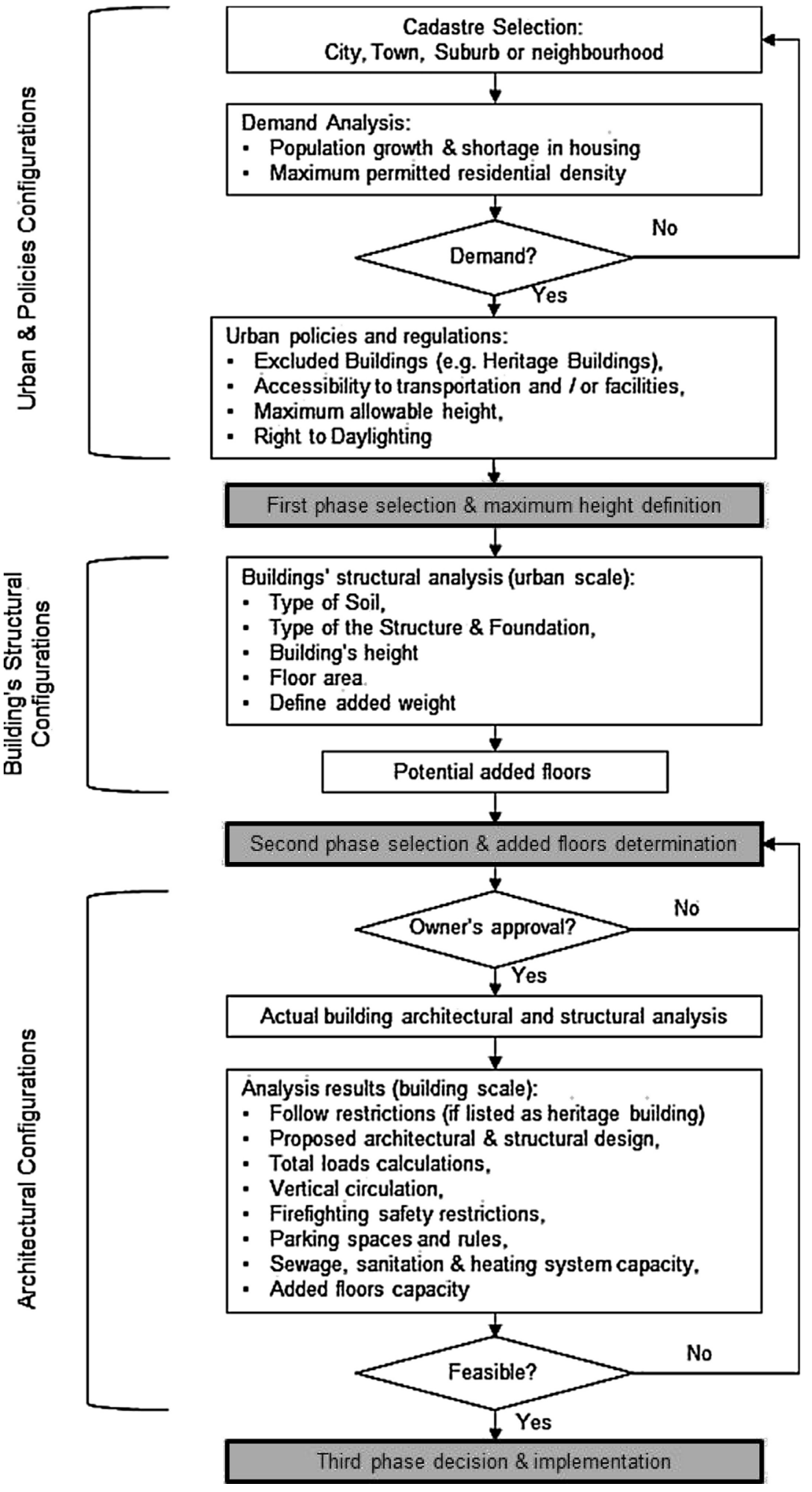

Fig. 1. Workflow chart.

Urban policies and regulations:
- Excluded Buildings (e.g. Heritage Buildings).
- Accessibility to transportation and / or facilities,
- Maximum allowable height.
- Right to Daylighting

I

First phase selection \& maximum height definition

Buildings' structural analysis (urban scale):

ure \& Foundation,

Floor area

Analysis results (building scale):

Sewage, sanitation \& heating system capacity.

Added floors capacity

Third phase decision \& implementation categories. The first category is public housing, which takes a $10 \%$ share of the housing units. Under the first category, there are two types of public housing provided by the government. One of these is social housing, which covers only $15 \%$ of the public housing development and consists of rentable housing for low-income households. One disadvantage of this type of public housing is the long waiting period between application and actual habitation. The remaining share of the public housing is in the form of subsidised housing, based on a public- private partnership, for which the cost of a square meter should not exceed 1500 EUR. This type of housing targets middle-income households. The second category, which takes a $70 \%$ share of the housing units, is for private market built by private developers. The third category, with a $20 \%$ share of the total annual housing units, is basically for private ownership (Dessouroux \& Romainville, 2011; Vanneste, Thomas, \& Vanderstraeten, 2008).

Accordingly, there is an obvious shortage in the provisioning of 
housing for the low- and middle-income social classes, which creates a burden on the government to change its policies toward providing more housing for these classes (De Decker, 1990, 2008). The first reason behind the current lack of supporting public housing is the limited amount of public land that can be directed toward public housing. The second reason is the fact that the majority of the homes offered are more appropriate for the higher economic classes and less so for the economically lower ones because the price of land per square meter in Brussels is very high compared with peri-urban and rural areas in Belgium. The third reason is due to the "not in my back yard" (NIMBY) effect, in which existing residents oppose social housing projects that are close to them. However, according to the Royal Decree "Urban Planning Charges", new regulations require 30\% social housing, in some conditions, for new developments. Nevertheless, it is important to find new opportunities for land for middle-income households. In this section, the methodology developed to assess roof stacking potential is examined using the Brussels Capital Region as a case study to identify and quantify the number of dwellings that could be provided only through roof stacking and to answer the question of whether roof stacking can be a successful alternative solution to accommodate the expected population growth with a reasonable increase in urban density.

\subsection{Urban \& policies configurations}

\subsubsection{Heritage buildings}

Brussels comprises five sites under the protection of UNESCO, where urban intervention in the form of building densification is severely limited. Additionally, there are various sites subject to strong heritage protection. For zones of strong protection, intervention by roof stacking is excluded completely, so these zones were withdrawn from our mapping process of the densification potential of Brussels. There are also various sites subject to weak heritage protection. The weak protection zone has a restrictive criterion for densification of buildings, but it does not completely prohibit densification; therefore, we did include these areas in our mapping process of the densification potential of Brussels.

\subsubsection{Accessibility to transportation}

An important challenge related to all forms of densification of the urban population is mobility and accessibility of various transportation infrastructures. The increase in population combined with an improved supply of public transportation and soft mobility networks should help Brussels embark on a transition toward more sustainable modes of transportation. In Brussels, the possibility that public transportation could absorb the expected population growth is quite feasible. The accessibility to public transportation in the Brussels-Capital areas is high (COOPARCH-RU, 2013): areas located within a radius of $600 \mathrm{~m}$ around primary public transportation stops (metro and train stations) and within a radius of $400 \mathrm{~m}$ around tramway stops cover more than $60 \%$ of the whole area of the Brussels Capital Region, and a large number of bus stops completes this potential. Moreover, a reasoned densification of Brussels should include the reinforcement of infrastructures for the soft modes network of transportation in order to facilitate walking, bicycling, and using electric bicycles, which have a real potential in urban environments because journeys are on average short. From this analysis, no building in the Brussels Capital Region was excluded from our mapping process of the roof stacking potential of Brussels on the basis of a lack of accessibility to transportation networks.

\subsubsection{Accessibility to parking areas}

In Brussels, it should be easy to provide additional parking space for roof-stacked buildings in the peripheral zones because of the low build density there, but in the very dense areas of the city centre, location of these additional parking spaces is an essential requirement for good acceptance of urban densification. Even if the problem of establishing a car park is managed on a case-by-case basis, regional authorities could effectively increase parking spaces to meet the demand of the projected densification by adding parking levels to existing open-air car parks.

The number of car parks currently located in the Brussels Capital Region according to the Ministère la Région du Bruxelle Capital (MRBC) is 9425 different parking areas, including 325 car parks with an area of more than $1000 \mathrm{~m}^{2}$ each (COOPARCH-RU, 2013). The threshold of $1000 \mathrm{~m}^{2}$ was chosen for two reasons. First, it corresponds to a car park with a capacity of 50 cars, using an average area of $20 \mathrm{~m}^{2}$ per car (parking plus traffic infrastructure between parking spaces), and second, open-air parking areas of more than $1000 \mathrm{~m}^{2}$ represent a realistic potential for adding additional levels. These open-air car parks of more than $1000 \mathrm{~m}^{2}$ in Brussels currently cover $68,681 \mathrm{~m}^{2}$ of parking area on a single level. This area provides potential for substantially increasing the number of parking spaces in Brussels. Finally, a modal shift to public transportation, carpooling and shared car systems, and soft mobility that does not include motorised transportation, such as walking and bicycling (La Rocca, 2010), should be encouraged. From this analysis, no building in the Brussels Capital Region was excluded from our mapping process of the roof stacking potential of Brussels on the basis of a lack of accessibility to parking area.

\subsubsection{Accessibility to public green spaces}

There are nearly 4,000 ha of green spaces in the Brussels Capital Region, representing approximately $25 \%$ of the territory. The density of public green spaces in 2010 was about $36 \mathrm{~m}^{2}$ per inhabitant (COOPARCH-RU, 2013), whereas the sustainable urban planning recommendation is at least $10 \mathrm{~m}^{2}$ of public green spaces per inhabitant (De Herde, Vermeir, Godart, Hanin, \& Reiter, 2009). Moreover, these green spaces are well distributed across Brussels' territory. From the perspective of accessibility to public green spaces, the population of Brussels could triple without any problem caused by roof stacking because densification by roof stacking increases the number of inhabitants without diminishing access to green spaces. There is therefore a very large potential for densification by roof stacking in Brussels with regard to green spaces. No building in the Brussels Capital Region was excluded from our mapping process of the roof stacking potential in Brussels on the basis of a lack of accessibility to green spaces.

\subsubsection{Maximum allowable building height}

According to the urban regulations of the Brussels Capital Region, the height of the front façade has to be determined in accordance with the height of the two neighbouring facades: it cannot be less than the lowest reference height, cannot be more than the highest reference height, and not be more than $3 \mathrm{~m}$ above the lowest reference height. However, the allowable height for new or roof-stacked buildings may also be determined as the mean average height of the other buildings on the street. For simplicity, this last rule (mean height of the buildings on the street block) was applied to fix the maximum allowable height for roof stacking in Brussels in our mapping process for scenario 1, corresponding to the actual urban regulation in Brussels. However, if we consider the possibility that this criterion of maximum height of buildings could be relaxed in the near future to facilitate the construction of new dwellings to accommodate the expected population increase, it seems important to select a minimum criterion of natural light accessibility, which is explained in detail in the following subsection.

\subsubsection{Accessibility to daylighting}

Preserving the natural daylighting of existing buildings during an urban densification operation is obviously essential. For Brussels, there are no well-defined rules imposed to ensure accessibility to natural light, but the maximum allowable building height is a very strict criterion that also ensures this right to daylighting of neighbouring buildings. International research recommendations provide for the 


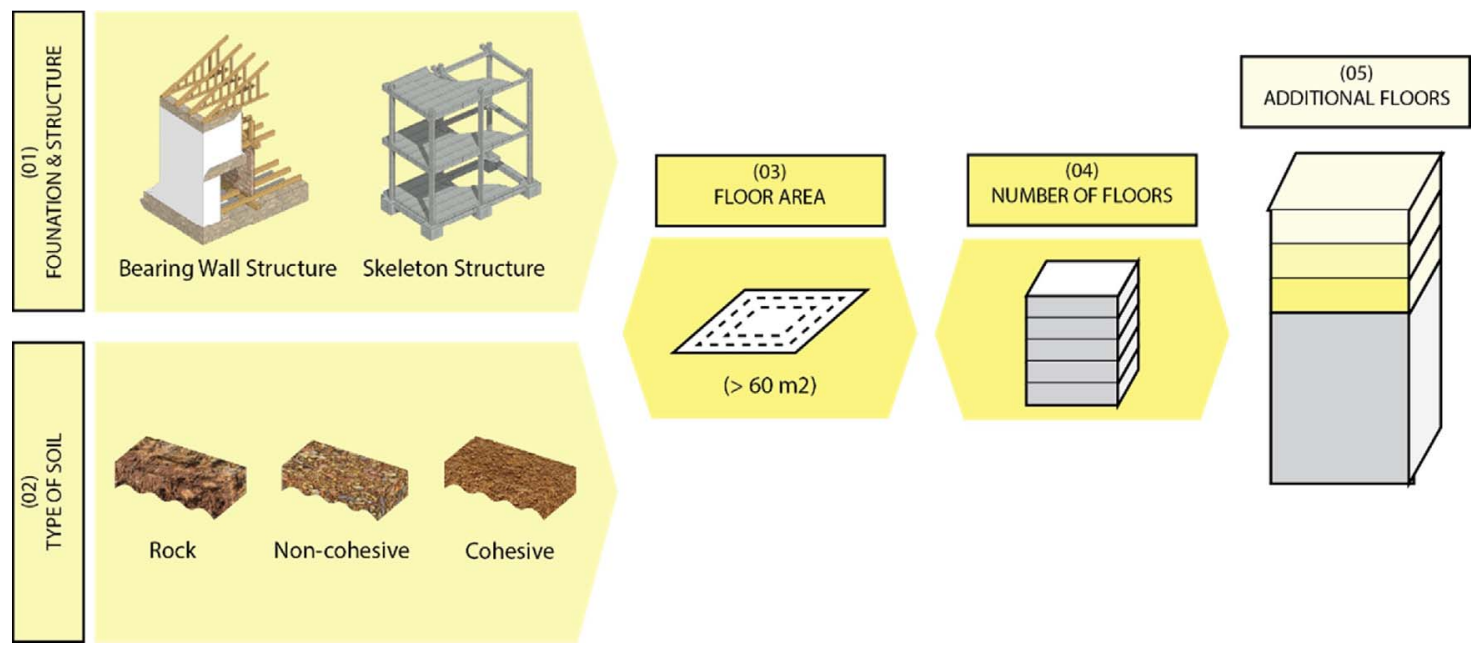

Fig. 2. Structural mapping for roof stacking potential.

latitude of Brussels an acceptable limiting obstruction angle equal to $25^{\circ}$, which must be taken from a height of $2 \mathrm{~m}$ above street level on the building's façade (Littlefair et al., 2000). From this rule, the maximum building height can be identified for each building based on the relation between street width and existing buildings heights. This rule was applied to fix the maximum allowable height for roof stacking in Brussels in our mapping process for scenario 2 , corresponding to an optimistic scenario for densification by roof stacking while still preserving the quality of life of neighbours.

\subsection{Structural configurations of buildings}

To estimate the potential number of stories that could be added to existing buildings, some information must be provided and investigated. However, at the urban level, detailed information can seldom be acquired, especially information pertaining to the structural analysis of existing buildings. Thus, in this method, a set of criteria to be utilised in a systematic approach to roughly estimate the potential number of floors that could be added to existing buildings using a minimum amount of information was developed. According to Fig. 2, some information is required to identify the potential for roof stacking: the type of existing building structure, soil properties, area of land plot, and number of existing floors. The estimated weight added per square meter is an additional piece information needed to estimate this potential number of added floors. However, in some cases, it is nearly impossible to acquire precise data from the GIS database at the building scale level, either because of an absence of resources or because there were onsite changes that were not updated in the database. Thus, estimations for building configuration and soil calculations were set as explained below.

\subsubsection{Building typology}

Existing residential buildings were categorised into two periods: residential buildings built before 1945 and residential buildings built between 1946 and 1975. Residential buildings that were built after 1975 were excluded from the analysis. The year 1945 marks the end of the WWII and the beginning of an industrialised period in the field of construction. Residential buildings constructed before 1945 represent $71 \%$ of the existing residential buildings in Brussels. The second threshold defined by the year 1975 was chosen as a threshold of the analysis and mapping process because the number of residential buildings built after 1975 is negligible. These buildings represent less than $3 \%$ of all the existing residential buildings and have a much greater disparity of architectural typologies and materials. The proportion of residential buildings built between 1945 and 1975 is 26\%, and the typologies used in the residential building sector did not change dramatically for the structural calculation of low- and mid-rise buildings. According to the De Taeye Law, housing production was directed away from large-scale, multi-storey, and collective housing projects until the late 1970s (Van de Voorde, Bertels, \& Wouters, 2015). Residential building typologies did not change dramatically, and people and construction industries were still conservative compared to other countries in Europe during this period. Changes were observed in the building materials used, such that heavy bricks were replaced with lightweight bricks and wooden masonry joist slabs were replaced with lightweight concrete slabs.

The illustration in Fig. 3 presents the percentages of the different residential building typologies before 1945 . The majority of buildings were classified as middle-class houses, which represent $78 \%$ of the total. Fig. 4 shows the typical layout of the middle-class house typology, which was selected in this study as a unified reference to building configurations in terms of percentage thickness of walls and foundation (Van de Voorde et al., 2015). Accordingly, building materials and their properties could be identified easily and unified in the mapping test process. In this example, the average weight of walls was identified to be $1900 \mathrm{~kg} / \mathrm{m}^{2}$, that of wooden slabs was estimated to be $100 \mathrm{~kg} / \mathrm{m}^{2}$, and live loads were $200 \mathrm{~kg} / \mathrm{m}^{2}$. For buildings constructed after WWII, the average weight of walls was identified to be $1200 \mathrm{~kg} / \mathrm{m}^{2}$, that of concrete slabs was $125 \mathrm{~kg} / \mathrm{m}^{2}$, and live loads remained constant (Van de Voorde et al., 2015).

\subsubsection{Soil allowable bearing capacity}

In Fig. 2, three main categories of soil are presented: rocky, noncohesive, and cohesive soil. It is important to note that this illustration

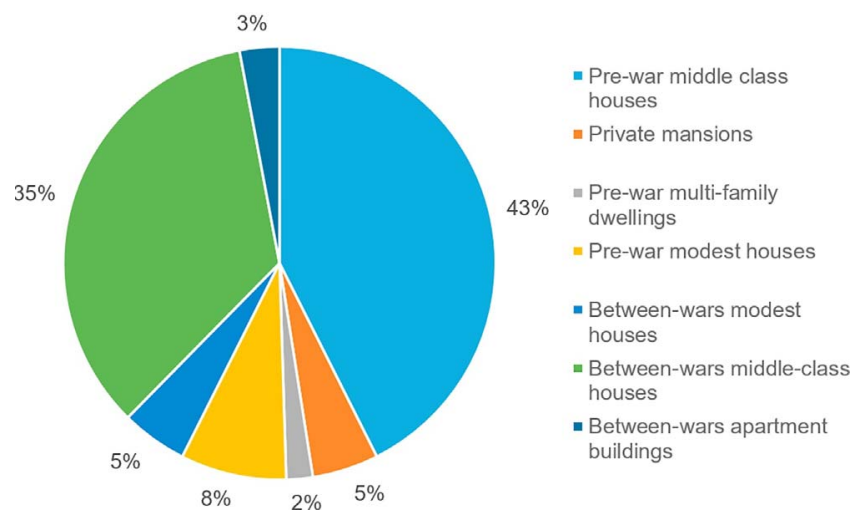

Fig. 3. Housing typologies before 1945. 


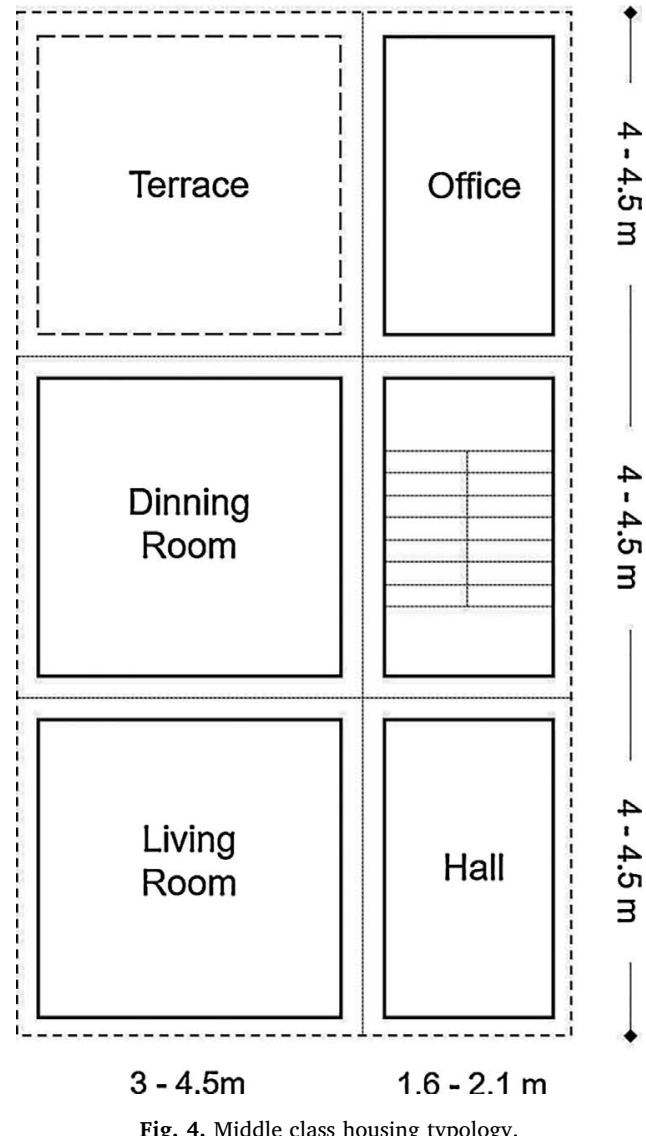

represents only a generalised concept rather than the actual soil types of the Brussels Capital Region. However, the actual soil lies within this categorisation. According to the soils map of Brussels, more than seven types of soil exists. However, two distinct types are identified. The dominant soil is called Bruxellien, which consists of sandy sediment in the upper part of the city but basically of silty sediment in the lower part of the city. Based on a unified estimation of the depth and width of foundation footage, the allowable soil bearing capacity was identified as being between $150 \mathrm{kN} / \mathrm{m}^{2}$ and $350 \mathrm{kN} / \mathrm{m}^{2}$, depending on the location of the building on the soil map of Brussels. This rule was applied in our mapping process for the roof stacking potential assessment.

\subsubsection{Floor area and number of floors}

Data of floor area and number of actual floors are available in the Brussels GIS database, which was used in this stage of the analysis. The data are updated yearly by the cadastre administration in the Ministry of Finance in Belgium. It was observed that $99 \%$ of the residential buildings have between 1 and 5 floors. Thus, in our mapping process of the densification potential, the analysis was carried out on only buildings with no more than 5 floors. Moreover, it is important to mention that the minimum calculated floor area in this process is $60 \mathrm{~m}^{2}$. The aim was to exclude any imprecisions in the maps provided by the GIS database and use the existing building typology.

\subsubsection{Estimated weight added per square meter}

The weight of the added stories is within the category of lightweight construction. However, the new construction weight cannot be identified precisely unless final architectural and structural drawings are available. In this case, the value was estimated based on other projects that used lightweight materials and reached a value of $120 \mathrm{~kg} / \mathrm{m}^{2}$ (Lawson et al., 2010), whereas practical and in-use lightweight housing modules reached $500 \mathrm{~kg} / \mathrm{m}^{2}$, including live loads (Amer \& Attia, 2017). This rule was applied in our mapping process for the densification potential by roof stacking of Brussels. In the broader context, it is important to mention that the building materials used for roof stacking should be compatible with the existing building materials, the structure of each building, and the local supplier in the city.

\section{Outcomes}

The results and values were carried out and post-processed using ArcGIS based on the developed methodology. The numerical results have strong variations; however, the maximum number of additional floors respects the allowable height given for each building. The legend colour on the generated map is divided into four categories: no, low, moderate, and high potential for roof stacking, which are equivalent to the resultant values for each building with respect to urban regulations and building strength (see Section 4). Low potential for roof stacking was applied to values equivalent to one added floor, moderate potential was applied for values equivalent to two added floors, and lastly, high potential was assigned to values equivalent to three or more added floors.

According to the case study of the Brussels Capital Region (BCR), several factors were found to affect the potential for densification dramatically. Assuming that the BCR consists of a core, a first urbanised periphery, and a second periphery, both peripheries have lower densities. The highest potential for roof stacking with respect to the actual urban regulations and the strength of buildings is in the first periphery (see Fig. 5) for two main reasons. The first reason, compared to the core of the city, which has the highest density values including neighbourhoods with a density equivalent to 362 inhabitants per hectare, the core cannot be further densified. The second reason is the average low mean height of the buildings in the second periphery, which limits the roof stacking potential in the less dense area due to the actual urban regulation.

On the basis of this observation, two different scenarios are presented in this research. The first scenario presents the potential for roof stacking in Brussels when applying the actual strict urban regulations. The second scenario presents a proposal in which urban regulations are not fully applied. The regulation related to allowable maximum height based on the mean height of the buildings on the street is excluded, and a more relaxed regulation related to the allowable maximum height based on daylight availability is proposed. This second scenario aims to increase the densification potential in neighbourhoods that currently have a low density and include many buildings with low height, while aiming to maintain outdoor environmental quality in addition to indoor daylight availability for neighbouring buildings. A second goal of this scenario is to facilitate the construction of a higher number of new dwellings to accommodate the expected population increase by 2040 . Consequently, the second scenario results in a higher potential for roof stacking, improving the ability of the city to accommodate greater population in the coming years. Additionally, each scenario consists of two steps based on the steps presented in the workflow chart: urban and policies configurations and building structural configurations. Thus, the first step presents the values according to the urban regulations of the $\mathrm{BCR}$, whereas the second step presents the values when considering the buildings' tendencies to hold more weight based on their actual structural capacity. The rationale for presenting both steps is to validate the proposed workflow chart by testing the influence of building strength on the resultant values. It is important to mention than the calculations were made based on the average living area consumed by an inhabitant, which is $35 \mathrm{~m}^{2}$. This area does not include the building service areas (stairs, hallways, etc.), which are equivalent to an addition of $9 \%$. Thus, the total consumption of floor area is equivalent to $38.15 \mathrm{~m}^{2}$ per inhabitant.

In the first scenario, by applying urban regulations (first step), it was found that the BCR is capable of hosting more than 60,400 additional inhabitants, which is equivalent to $32 \%$ of the expected increase in population. However, when considering the actual building strength 


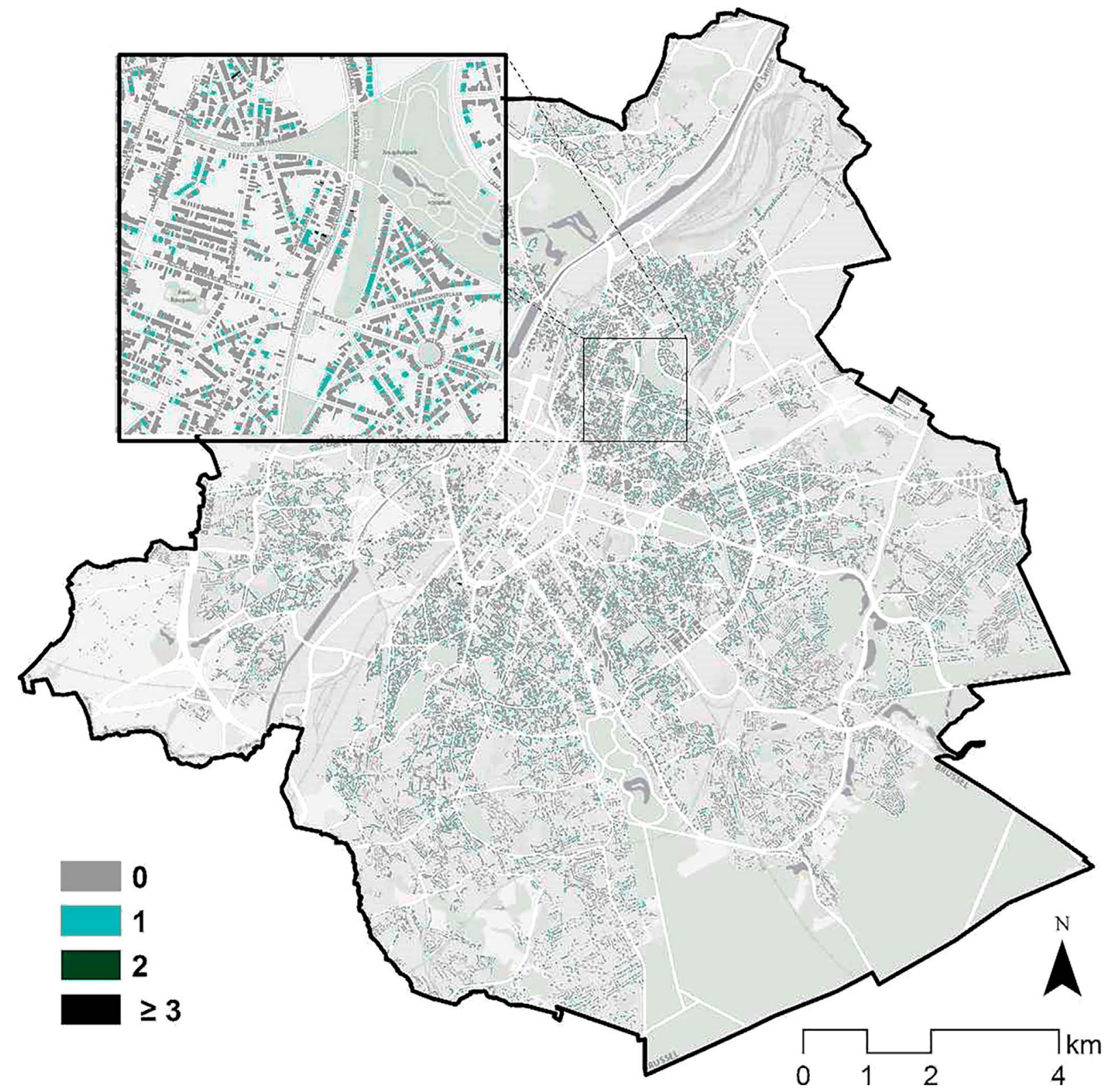

Fig. 5. Roof stacking potential presented in the number of additional floors with respect to strict urban regulations \& buildings strength.

(second step), as shown in Fig. 5, the number is only reduced to 59,000 additional inhabitants, which is equivalent to $30 \%$ of the expected increase in population, a difference of $2 \%$, which is equivalent to a roughly $50,000 \mathrm{~m}^{2}$ reduction of roof stacking potential. In Figs. 6 and 7 , the difference is presented at the municipality level, at which the $2 \%$ difference does not represent a large reduction due to the strict limitations provided by the actual urban regulations, which explains why Figs. 6 and 7 appear to be similar. This comparison is further presented with numbers in Table 3.

When applying the first step of the second scenario of analysis, corresponding to flexible urban regulations respecting the daylighting rule, the potential for roof stacking increases dramatically. It was found that the BCR is capable of hosting more than 655,500 additional inhabitants, which is equivalent to $245 \%$ more than the expected increase; however, when considering the actual building strength, the number is reduced to 509,000 additional inhabitants, $160 \%$ more than the expected increase in population. The influence of applying the structural configurations of the existing buildings in the calculation of roof stacking potential at the city scale in this second scenario is huge, equivalent to an $85 \%$ difference in the population increase potential between the first and the second steps, which is contrary with the first scenario. In Figs. 8 and 9, which present the two steps of the second scenario, the differences in the densification potential of these steps at the municipality level are obvious, as is further illustrated with numbers in Table 3.

In the second step of the second scenario of roof stacking, when given the opportunity to expand the maximum allowable height, it was found that the underlying soil greatly affects the final results by modifying the maximum load acceptable for the buildings and thus their calculated strength. In the case of the BCR, the soil in the eastern and southern parts of Brussels is called Bruxellien and consist of sandy sediment with high allowable bearing pressure, but in the northern and western parts of the city, the soil basically consists of silt with low allowable bearing pressure. Accordingly, when comparing the first and second steps in the second scenario, the difference in the potential for roof stacking in the municipalities in the north is $25 \%$, whereas the difference is only $16 \%$ in the municipalities in the south because these municipalities overlie stronger soil. However, from the technical 


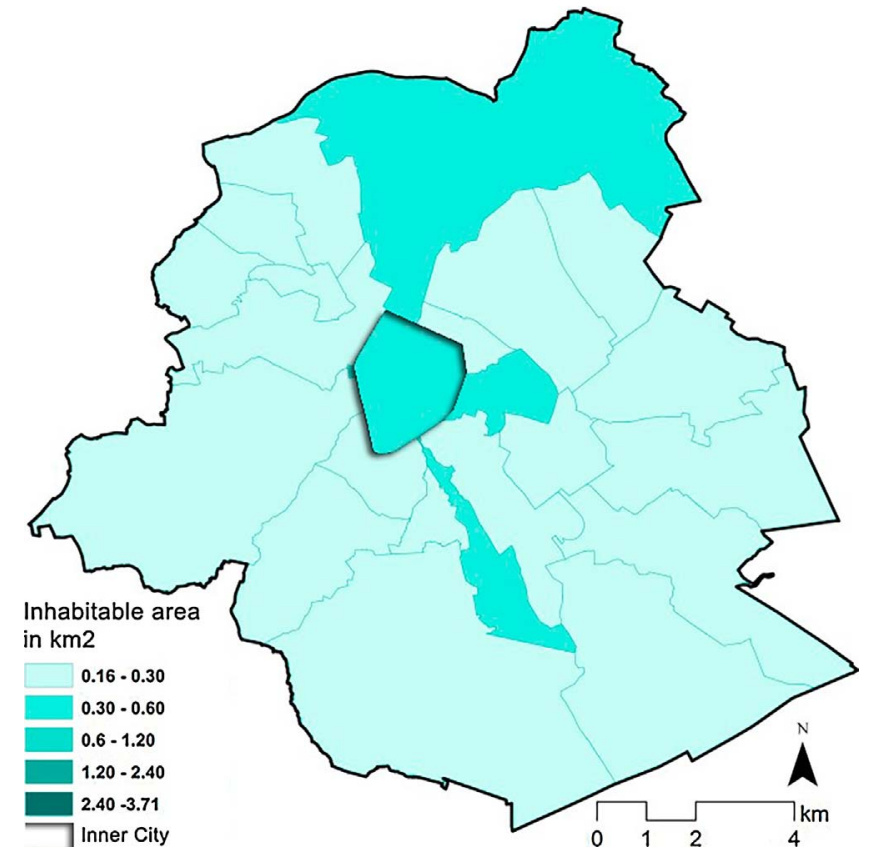

Fig. 6. Roof stacking potential in $\mathrm{km} 2$ per municipality respecting strict urban regulations only.

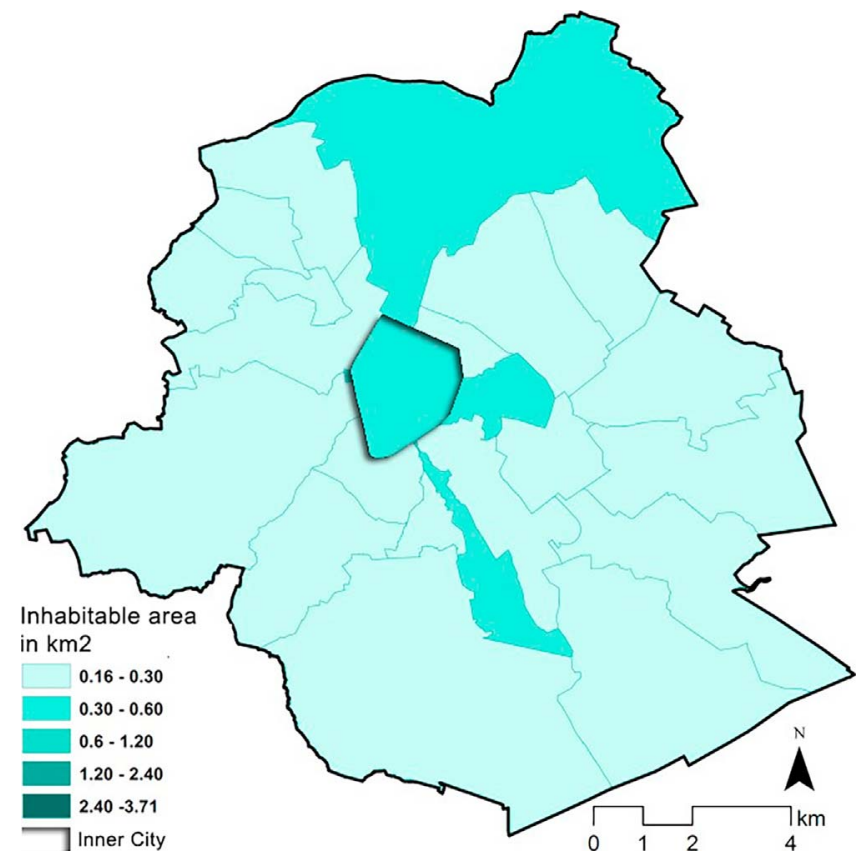

Fig. 7. Roof stacking potential in $\mathrm{km} 2$ per municipality respecting strict urban regulations \& buildings strength.

perspective, it is possible to increase the height of the existing buildings, adding floors on a building that cannot hold more weight requires additional reinforcement and therefore extra budget. Nevertheless, in this research, roof stacking that depends on the actual strength of the existing building and soil is only considered for reasons of cost efficiency. In the case study of Brussels, the roof stacking potential assessment relies on the total load bearing of the new structure on the existing bearing walls of the buildings, thus structural limitations affect these results.

The results produced for Brussels at the city scale using the second scenario show that there should be a real interest in re-examining the current urban regulations to take into account the great need for new housing in this city by 2040. Moreover, the potential number of dwellings produced by roof stacking densification based on this second scenario is enormous. However, such an increase in the building stock cannot be accomplished without simultaneously addressing different urban and social issues, such as increasing various urban services (schools, hospitals, etc.) and facilities, increasing the capacities of modes of public transportation in the densified parts of the city, having a global reflection on the alterations to urban morphology, social factors, and mobility issues, and assessing the impacts of this densification on urban sustainability, resiliency, and health. A first reflection on these aspects was already begun in Section 4, which defined our case study, but a concrete modification of the current urban planning regulation on the maximal building height in Brussels would require a more detailed study of these different aspects and of all the potential consequences of such an increase in population on the existing living environment of Brussels.

\section{Findings and discussion}

\subsection{Summary of the main findings}

We found that limiting urban sprawl requires two different but concurrent approaches, applying urban containment strategies while also moving toward urban densification. Three urban containment strategies and five urban densification strategies were identified in this research. Each strategy has its own advantages and disadvantages in addition to the settings that determine their best practice conditions. Yet, we focused in this research on the roof stacking method as a sustainable approach toward densification through providing an opportunity to use urban infrastructure with higher efficiency, accommodate population increase, and reduce the cost of energy consumption of existing buildings, while still conserving urban green spaces. We highlighted the interest in applying the roof stacking method in European cities, especially those cities under geographical constraints or with large expectations of population increase and demand for housing within the city.

This research developed an integrated methodology for mapping and quantifying the potential for increasing urban density through roof stacking at different urban levels, such as the city, suburb. and neighbourhood levels. This method is based on the combination of three consecutive levels of decision making for roof stacking: the urban regulation, engineering, and architectural levels. This three-level approach secures the inclusion of the applied policies at the city level (top-bottom approach), technical support by specialists in the fields of urban planning, architecture, and civil engineering (intermediate level), and the participation of society (grass roots approach) in the decision making process. We strongly note the need to adapt current urban policies and regulations at the city level to provide additional opportunity to apply, in a reasonable way and with consideration of the quality of life in the city, the different methods of densification, and specifically roof stacking, and also note the importance of motivating local inhabitants and tenants with this idea and promoting its financial, social, and environmental benefits at both the individual and societal scale.

This research developed a detailed method for mapping the roof stacking potential with screening criteria. The method calculates the capacity of existing buildings to support additional floors added to the roof top, which is used simultaneously in the whole workflow of the decision making process. The screening criteria were transformed into a coding language within ArcGIS software for application to the Brussels Capital Region. We found that the GIS-based experiential information presented in this paper can be a valuable addition to other layers of analytical information in the geographical information system for urban planners and decision makers where the use of multiple types of information and their analysis are essential elements of planning. Through the application and the validation of the methodology for the Brussels Capital Region, it was found that the city can accommodate 
Table 3

The potential area in square meter of roof stacking per municipality in Brussels Capital Region.

\begin{tabular}{|c|c|c|c|c|c|c|}
\hline Municipality & Scenario $1.1\left(\mathrm{~m}^{2}\right)$ & Scenario $1.2\left(\mathrm{~m}^{2}\right)$ & Difference (\%) & Scenario $2.1\left(\mathrm{~m}^{2}\right)$ & Scenario $2.2\left(\mathrm{~m}^{2}\right)$ & Difference (\%) \\
\hline Brussels & 347,590 & 335,292 & $3.5 \%$ & $3,110,873$ & $2,304,217$ & $25.9 \%$ \\
\hline Uccle & 254,175 & 253,877 & $0.1 \%$ & $3,705,901$ & $2,924,293$ & $21.1 \%$ \\
\hline Schaerbeek & 239,681 & 234,235 & $2.3 \%$ & $2,571,445$ & $1,865,630$ & $27.4 \%$ \\
\hline Anderlecht & 186,051 & 179,712 & $3.4 \%$ & $2,049,771$ & $1,500,785$ & $26.8 \%$ \\
\hline Ixelles & 168,329 & 168,361 & $0.0 \%$ & $1,317,597$ & $1,160,589$ & $11.9 \%$ \\
\hline Forest & 140,706 & 134,388 & $4.5 \%$ & $1,129,145$ & 794,581 & $29.6 \%$ \\
\hline Woluwe St. Pierre & 132,784 & 132,791 & $0.0 \%$ & $1,957,348$ & $1,649,133$ & $15.7 \%$ \\
\hline Etterbeek & 116,335 & 116,340 & $0.0 \%$ & 907,854 & 714,278 & $21.3 \%$ \\
\hline Molenbeek St. Jean & 115,870 & 108,162 & $6.7 \%$ & $1,004,072$ & 555,645 & $44.7 \%$ \\
\hline Woluwe St. Lambert & 99,938 & 99,794 & $0.1 \%$ & $1,386,510$ & $1,177,485$ & $15.1 \%$ \\
\hline Jette & 89,048 & 88,880 & $0.2 \%$ & 981,695 & 786,070 & $19.9 \%$ \\
\hline St-Gilles & 87,976 & 80,579 & $8.4 \%$ & 581,045 & 408,193 & $29.7 \%$ \\
\hline Berchem St. Agathe & 64,216 & 64,219 & $0.0 \%$ & 625,708 & 520,949 & $16.7 \%$ \\
\hline Auderghem & 58,386 & 58,124 & $0.4 \%$ & $1,019,980$ & 889,881 & $12.8 \%$ \\
\hline Evere & 54,758 & 54,751 & $0.0 \%$ & 677,113 & 554,895 & $18.0 \%$ \\
\hline Watermael-Boitsfort & 48,183 & 48,178 & $0.0 \%$ & $1,061,831$ & 889,865 & $16.2 \%$ \\
\hline Koekelberg & 39,430 & 38,616 & $2.1 \%$ & 288,169 & 203,650 & $29.3 \%$ \\
\hline Ganshoren & 30,859 & 30,745 & $0.4 \%$ & 413,737 & 356,363 & $13.9 \%$ \\
\hline St. Joost & 29,362 & 29,017 & $1.2 \%$ & 219,382 & 165,508 & $24.6 \%$ \\
\hline
\end{tabular}

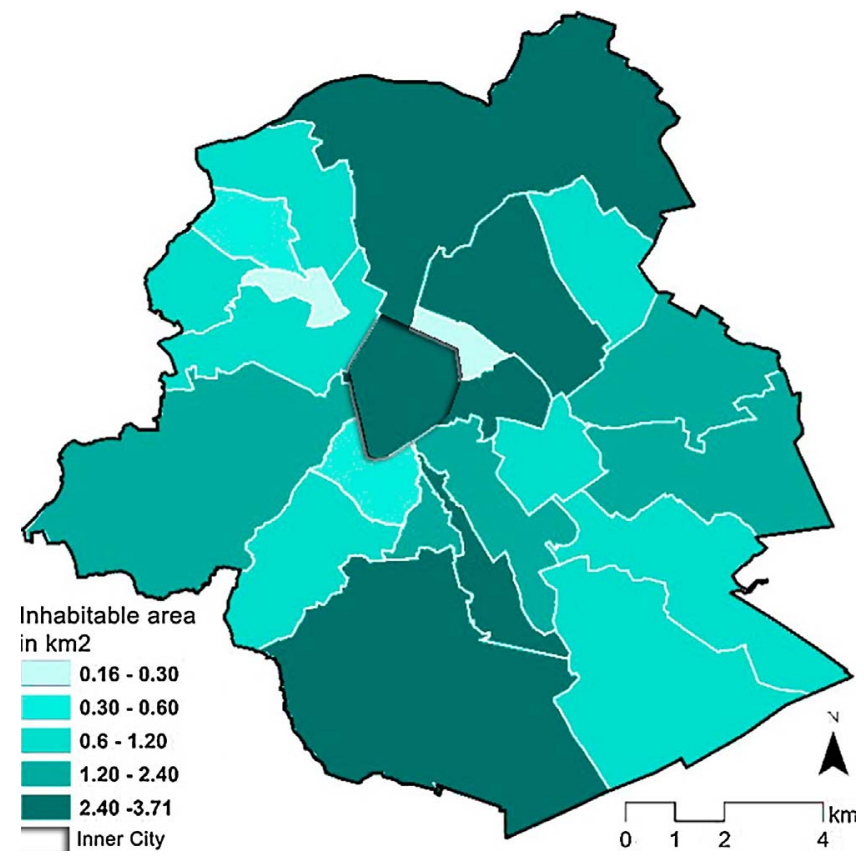

Fig. 8. Roof stacking potential in $\mathrm{km}^{2}$ per municipality respecting flexible urban regulations only.

more than 59,000 additional inhabitants, which represents approximately $30 \%$ of the expected increase in population by 2040 , by applying only roof stacking and increasing the height of existing buildings, while still respecting the actual urban regulations and the building strengths. In addition, a theoretical potential was proposed to accommodate more than the expected population increase by the same year, provided that the urban planning regulations are relaxed with regard to the height of buildings in the less dense area.

The results were compared to the results of previous research on urban densification in Brussels. In total, there are 887.6 ha in the Brussels Capital Region that are constructible and therefore available for densification. However, these areas are currently empty. Out of the total area, 185.6 ha of net land value is directed toward infill building land for housing and 702 ha is allocated for large urban projects (COOPARCH-RU, 2013). These areas of large urban projects can be used to build residential buildings and urban services and to establish new areas of economic activity and facilities, such as schools, hospitals,

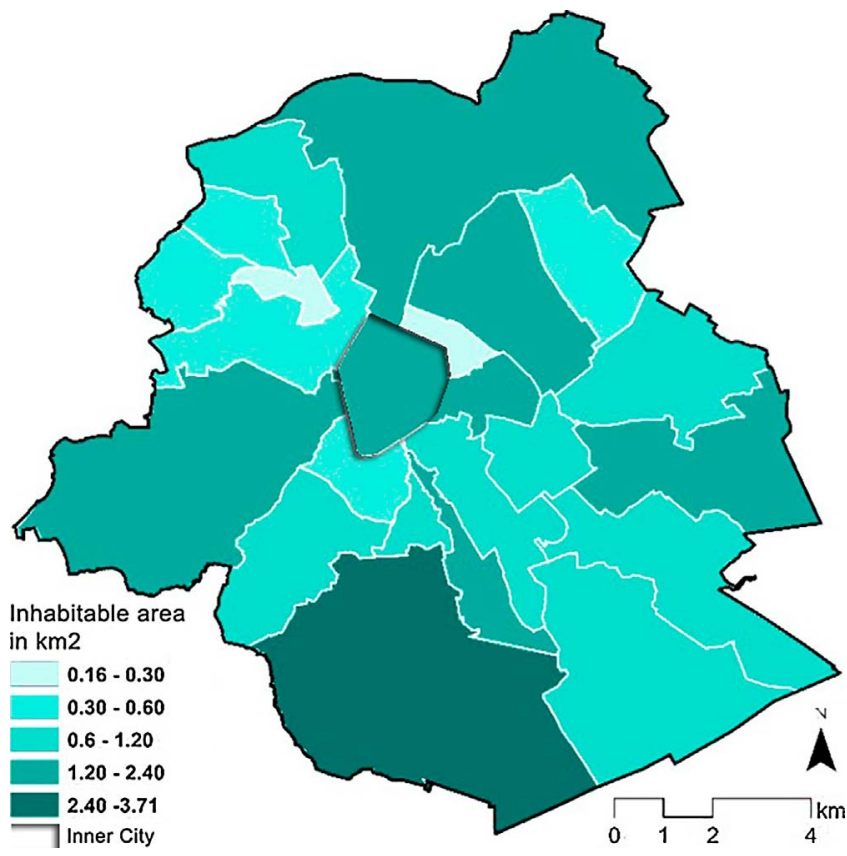

Fig. 9. Roof stacking potential in $\mathrm{km}^{2}$ per municipality respecting flexible urban reg ulations \& buildings strength.

sports facilities, and cultural facilities. If we consider that 185.6 ha, which is equivalent to $1.856 \mathrm{~km}^{2}$, could be used for infill development, an estimated $20 \%$ of this amount can be allocated to building uninhabitable areas such as walls, which leaves only $80 \%$ of the total area, equivalent to $1.48 \mathrm{~km}^{2}$, for net residential functions. When this number is multiplied by 4 , for an estimated 4 floors per building, it gives us a total of $5.93 \mathrm{~km}^{2}$ of inhabitable area. Compared to the given potential by roof stacking, which is equivalent to $2.256 \mathrm{~km}^{2}$ in the first scenario, we find that infill development has a potential for accommodating population that is more than two times higher that of the lowest estimate of roof stacking.

Thus, it seems preferable to retain a large part of the large urban projects in the city and to develop on these areas all the urban uses other than housing. This solution makes it possible to retain the potential to increase urban services and economic activities in parallel with densification of the population. The potentials of roof stacking and infill development can be combined to achieve the desired 
densification.

Moreover, there is enormous potential for land availability in the peripheral area of Brussels, where there are more than 6,000 ha of land available for housing in Walloon Brabant and 3,800 ha available in Flemish Brabant (COOPARCH-RU, 2013). These areas, however, must remain the last densification solution because they are poorly served by public transportation, in particular, and because their development would increase urban sprawl.

It is important to consider that these values count only the estimated urban and structural potential of adding additional buildings or floors, without considering the social acceptance for each specific building plot, which will reduce these theoretical potentials. Yet, the key strength of this the proposed methodology is its ability to create maps and aid in decision making with the least amount of information.

\subsection{Strengths and limitations of the research}

Our work is the first of its kind to map urban densification potential by means of roof stacking. However, there have been other attempts at producing densification maps based on either abstract information on spaces and heights or merely on visual inspection. The methodology proposed in this research is precisely defined, and its application to the case study of Brussels is replicable. The method is parameterised and reproducible in other territories and at different scales and locations.

In this research, the methodology was applied using the case study of the Brussels Capital Region. However, the number of dwellings that can be created by roof stacking based on our study cannot represent the real value of probable densification through roof stacking in the near future; it represents only the maximal potential of roof stacking densification on the basis of our calculation assumptions. These assumptions include, for example, the actual urban regulations, but do not take into account the social acceptability that would be expressed by the building owners or neighbours. There are also limitations to this study pertaining to the level of precision of the data entry. For instance, the selection process of the tested buildings, which were built before 1975, was chosen for examination. The reason behind this selection was to guarantee roughly unified building materials and construction techniques. Therefore, buildings materials and their weights were estimated based on interviews with local experts in the field of construction and used in the calculation process with the main building typologies. Moreover, all buildings built before 1975 were taken into account, although some of these should preferably be destroyed (due to degradation or lack of maintenance during the history of the building) and others may have already been renovated extensively. Nevertheless, for a study at the city scale, these assumptions seem quite reasonable.

Lastly, the structural calculation in the second phase of the workflow chart is based on analysing the dominant housing prototype in Brussels, which creates a certain level of uncertainty in the numerical results. Of course, more detailed information will be used in the third phase of our methodology.

\subsection{Future work}

This research provides a universal methodology applicable to any city in Europe that needs to be densified to accommodate additional population and increase the energy and resource efficiency of its built environment. However, the proposed methodology requires the usage of each city's local regulations and targets, such as targeted density, building regulations, maximum height levels, microclimate, mobility, infrastructure capacity, and urban health. Moreover, it requires stakeholder involvement in the decision making and planning process (OECD, 2017). Thus, further application of this methodology for different cities would help refine any unexpected errors or missing information, which consequently would increase the method's robustness and validity for creating densification maps for roof stacking at the city level in different contexts. In addition, for the application to Brussels and validation of the workflow, we only went through the first two phases of the workflow. Accordingly, to valorise the research outcomes of the third phase, onsite implementations of cases of roof stacking need to take place, which would intensively include the third part of the workflow chart in the process.

We are aware of the importance of social acceptability when addressing urban densification and city compactness (Burton et al., 1996). Thus, integrated research related to social acceptability is vital to investigate the parameters that affect the acceptability potential of roof stacking at the neighbourhood level. Such a process would include onsite surveys of neighbours and the homeowners whose properties have potential to be extended vertically based on the outcomes of this research. It is important to mention that the main focus of this research was to provide a methodology that would serve as a framework for decision makers at the city level for running quantitative analyses and achieving numerical expectancies to provide guidance for adapting urban regulations and subsidies. Thus, the case study aimed to validate the practicality of the workflow chart for decision makers, rather than to provide final numbers for future roof stacking projects. Moreover, the development of a sustainability indicator for efficient urban densification through roof stacking will be essential for implementation at the urban and strategic levels (Williams, 1999).

Lastly, further applications to different cities throughout Europe would help valorise the applied methodology and open further opportunities to develop an automated tool for estimating potentials with a wider scope. Indeed, for further usability, an automated open source tool used by various GIS software products would help planners and specialists improve data entry at the regional level and create an open discussion platform for developing that tool and creating multiple maps.

\section{Conclusion}

Presently, urban planning agendas are promoting reasonable urban densification as a sustainable development approach toward increasing the compactness of cities. From this approach, this research presented a workflow scheme to support decision making while simultaneously identifying and mapping the potential for roof stacking. This article was developed in three phases: (1) a literature review, (2) development of a decision-making workflow and various screening criteria for assessment of roof stacking potential, and (3) validation of the proposed methodology using a case study: the Brussels Capital Region. This case study demonstrated the applicability of the developed workflow on a real city. The roof stacking potential in Brussels, based on the actual urban regulations (including a strict rule on building maximal height), provides $30 \%$ of the additional required residential living space in Brussels needed by 2040 due to population increase. These results also show a real need for re-examining current urban regulations from the perspective of the roof stacking densification potential of cities, which are facing a need for a large number of new housing structures in the near future and a need for energy improvements of their old buildings stocks, provided that the consequences of this type of urban densification on the quality of life of the city's inhabitants are studied on a case-by-case basis and taken into account for sustainability.

Several challenges deter progress in developing such roof stacking projects on a broad scale. Some are specifically related to Brussels, and others could be universal, such as the "not in my back yard" (NIMBY) effect, which is the tendency of inhabitants to resist housing development projects in their neighbourhood. Those that are specifically related to Brussels include the high price of housing construction. This tends to increase the gap between real demand and supply in the housing market and create a shortage in providing social housing. Another challenge is related to the housing market being constrained to ownership rather than to renting. However, the figures in Brussels show that renting is still higher than ownership, but it is relatively low compared to other cities in Europe, such as Berlin (Vanneste et al., 
2001).

In conclusion, European cities have great potential to be densified through the roof stacking method. However, it is important to mention that a successful process of roof stacking should integrate each of the urban and regulatory, technical and engineering, and architectural and social participation aspects. Thus, this article presented a strategic approach for roof stacking, while strengthening the importance of following a multidisciplinary and institutional approach in the application of such projects.

\section{Acknowledgments}

This research was funded by a welcome grant provided by Liege University, which are gratefully acknowledged. This publication is part of the research project 2016-2020 entitled: DenCity Prototype: Concepts of Zero Energy Lightweight Construction Households for Urban Densification. We would like to acknowledge Sanae Ahayan from the Geomechanics and Engineering Geology lab for generating the bearing capacity calculations of the soil maps of Brussels. And we would like to thank Constance Uyttebrouck from the Local Environment Management and Analysis (LEMA) lab for providing valuable references and statistics for housing in Brussels.

\section{References}

Amer, M., \& Attia, S. (2017). Roof stacking: Learned lessons from architects. Belgium: SBD Lab, Liege University. Retrieved from http://orbi.ulg ac.be/handle/2268/210472.

Angel, S., Parent, J., Civco, D. L., \& Blei, A. M. (n.d.). The persistent decline in urban densities: Global and historical evidence of sprawl. ResearchGate. Retrieved from https:// www.researchgate.net/publication/265570541 The_Persistent Decline in Urban Densities_Global_and_Historical_Evidence_of_'Sprawl'.

Attenberger, T. (2014, August 14). Stadtentwicklung in Köln Lückenschluss in der Innenstadt. Retrieved from http://www.ksta.de/koeln/stadtentwicklung-in-koelnlueckenschluss-in-der-innenstadt-638998.

Attia, S., \& De Herde, A. (2010). Towards a definition of zero impact buildings. Techne Press. Retrieved from http://orbi.ulg.ac.be/handle/2268/162606.

Attia, S. (2015). Overview and recommendation on urban densification potential in Liège. Belgium. Retrieved from http://orbi.ulg.ac.be/handle/2268/182805.

Attia, S. (2016). Towards regenerative and positive impact architecture: A comparison of two net zero energy buildings. Sustainable Cities and Society, 26, 393-406. http://dx. doi.org/10.1016/j.scs.2016.04.017 ISSN 2210-6707.

Attia, S. (2017). Regenerative and positive impact architecture: Learning from case studies. London, UK: Springer International Publishing ISBN: 978-3-319-66717-1.

Bengston, D. N., \& Youn, Y.-C. (2006). Urban containment policies and the protection of natural areas: The case of Seoul's greenbelt. Retrieved from http://www.nrs.fs.fed.us/ pubs/4920.

Bolleter, J., \& Ramalho, C. E. (2014). The potential of ecologically enhanced urban parks to encourage and catalyze densification in greyfield suburbs. Journal of Landscape Architecture, 9(3), 54-65. http://dx.doi.org/10.1080/18626033.2015.968418.

Bonifazi, C., Okólski, M., Schoorl, J., \& Simon, P. (Eds.). (2008). International migration in Europe: New trends and new methods of analysisAmsterdam: Amsterdam University Press. Retrieved from http://dare.uva.nl/aup/nl/record/301879.

Boyko, C. T., \& Cooper, R. (2011). Clarifying and re-conceptualising density. Progress in Planning, 76(1), 1-61. http://dx.doi.org/10.1016/j.progress.2011.07.001.

Breheny, M. (1992). The contradictions of the compact cities. In M. Breheny (Ed.). Sustainable development and urban form. London: Pion.

Breheny, M. (1997). Urban compaction: feasible and acceptable? Cities, 14(4), 209-217.

Brunner, J., \& Cozens, P. (2013). Where have all the trees gone? Urban consolidation and the demise of urban vegetation: A case study from western Australia. Planning Practice \& Research, 28(2), 231-255. http://dx.doi.org/10.1080/02697459.2012. 733525.

Burton, E., Williams, K., \& Jenks, M. (1996). The compact city and urban sustainability: Conflicts and complexities. In M. Jenks, E. Burton, \& K. Williams (Eds.). The compact city: A sustainable urban form?. London: E \& FN Spon.

Burton, E., Jenks, M., \& Williams, K. (2013). Achieving sustainable urban form. Routledge.

Byomkesh, T., Nakagoshi, N., \& Dewan, A. M. (2012). Urbanization and green space dynamics in Greater Dhaka, Bangladesh. Landscape and Ecological Engineering, 8(1), 45-58. http://dx.doi.org/10.1007/s11355-010-0147-7.

COOPARCH-RU (2013). Inventaire des lieux de densification potentielle de la RBC. Bruxelles: Région de Bruxelles-Capitale.

Davison, I. (1995). Brave new world? Can cities really match the aspirations of home owners? Housebuilder Febreuary 3.

De Decker, P. (1990). Housing and housing policy in flanders (Belgium); confusion on the eve of a new decade. The Netherlands Journal of Housing and Environmental Research, 5(1), 3-27. http://dx.doi.org/10.1007/BF02525007.

De Decker, P. (2008). Facets of housing and housing policies in Belgium. Journal of Housing and the Built Environment, 23(3), 155-171. http://dx.doi.org/10.1007/ s10901-008-9110-4.
De Herde, A., Vermeir, G., Godart, M.-F., Hanin, Y., \& Reiter, S. (2009). DRUPSSuC: Design and Renovation of Urban Public Spaces for Sustainable Cities, Final report Phase 1 Brussels. Retrieved from http://orbi.ulg.ac.be/handle/2268/29459.

Dearborn, K., \& Gygi, A. (1993). Planner's Panacea or Pandora's Box: a realistic assessment of the role of urban growth areas in achieving growth management goals. Seattle University Law Review, 16(3), 975.

Deboosere, P. (2010). Brussels: a city, a region, a place to live. What does geography teach us about the future of Belgium's institutions, Re-Bel e-book 7. Retrieved from http://www. rethinkingbelgium.eu/rebel-initiative-files/ebooks/ebook-7/Re-Bel-e-book-7.pdf.

Dessouroux, C., \& Romainville, A. (2011). La production de logements en Belgique et à Bruxelles -Acteurs, dynamiques, géographie. EchoGéo, 15, 20.

Dessouroux, C., Bensliman, R., Bernard, N., Laet, S., De Demonty, F., Marissal, P., \& Surkyn, J. (2016). Note de synthèse BSI. Vol. 99, Le logement à Bruxelles: diagnostic et enjeux.

EEA (2006). Urban sprawl in europe (10/2006). Retrieved from http://www.eea.europa. eu/publications/eea_report_2006_10.

Floerke, P., Weiß, S., Stein, L., \& Wagner, M. (2014). Typologienkatalog - gebäudeaufstockungen. bauforumstahl e.V.. Retrieved from https://www.bauforumstahl.de/ upload/publications/150301_Typologienkatalog_Onlineausgabe_k.pdf.

Gennaio, M.-P., Hersperger, A. M., \& Bürgi, M. (2009). Containing urban sprawl-Evaluating effectiveness of urban growth boundaries set by the Swiss Land Use Plan. Land Use Policy, 26(2), 224-232. http://dx.doi.org/10.1016/j.landusepol. 2008.02.010.

Gordon, P., \& Richardson, H. W. (1997). Are compact cities a desirable planning goal? Journal of the American Planning Association, 63(1), 95-106. http://dx.doi.org/10. 1080/01944369708975727.

Haaland, C., \& van den Bosch, C. K. (2015). Challenges and strategies for urban greenspace planning in cities undergoing densification: A review. Urban Forestry \& Urban Greening, 14(4), 760-771. http://dx.doi.org/10.1016/j.ufug.2015.07.009.

Howley, P. (2009). Attitudes towards compact city living: Towards a greater understanding of residential behaviour. Land Use Policy, 26(3), 792-798. http://dx.doi.org/ 10.1016/j.landusepol.2008.10.004.

ISO 13822 (2010). Bases for design of structures. Assessment of existing structures. Retrieved from http://www.iso.org/iso/catalogue_detail? csnumber $=46556$.

Jenks, M., \& Colin, J. (2010). Dimensions of the sustainable city. Springer. Retrieved from http://www.mopt.org.pt/uploads/1/8/5/5/1855409/mikejenks.pdf.

Knight, C. (1995). The pitfalls of town cramming. Planning Week 8 June, 14.

La Rocca, R. A. (2010). Soft mobility and urban transformation. TeMaLab Journal of Mobility, Land Use and Environment, 3, 85-90.

Lawson, M., Baddoo, N., Vannier, G., Doering, B., Kuhnhenne, M., Nieminen, J., ... Kozlowski, A. (2010). WP 5.3.3. high quality roof - top extension in rotterdam (Renovation of buildings using steel technologies (ROBUST) No. WP 3). The Stee Construction Institute (SCI). Retrieved from http://www.steel-renovation.org.

Littlefair, P., Santamouris, M., Alvarez, S., Dupagne, A., Hall, D., Teller, J., .. Papanikolaou, N. (2000). Environmental site layout planning: Solar access, microclimate and passive cooling in urban areas. CRC. Retrieved from http://orbi.ulg.ac.be/handle/ $2268 / 28963$.

Marique, A.-F., \& Reiter, S. (2014a). Retrofitting the suburbs: Insulation, density, urban form and location. Retrieved from Environmental Management and Sustainable Development, 3(2)http://orbi.ulg.ac.be/handle/2268/173790.

Marique, A.-F., \& Reiter, S. (2014b). A simplified framework to assess the feasibility of zero-energy at the neighbourhood/community scale. Retrieved from Energy and Buildings, 82, 114-122. https://orbi.ulg.ac.be/handle/2268/170408.

Marique, A.-F., Dujardin, S., Teller, J., \& Reiter, S. (2013). Urban sprawl, commuting and travel energy consumption. Proceedings of the Institution of Civil Engineers Energy, 166(1), http://dx.doi.org/10.1680/ener.12.00002.

Marshall, J. D. (2007). Urban land area and population growth: A new scaling relationship for metropolitan expansion. Urban Studies, 44(10), 1889-1904. http://dx.doi. org/10.1080/00420980701471943.

Nilsson, R., Blomsterberg, A., \& Landin, A. (2016). Vertical extension of buildings as an enabler of energy Renovation. Presented at the unpublished. Retrieved from http://lup. lub.lu.se/record/dd54b589-d3f1-44b2-ab99-3c7ef9c666ce.

OECD (2001). International mobility of the highly skilled. Paris: Organisation for Economic Co-operation and Development. Retrieved from $\backslash$ ] http://www.oecd-ilibrary.org/ content/book/9789264196087-en.

OECD (2012). Compact city policies. Paris: Organisation for Economic Co-operation and Development. Retrieved from http://www.oecd-ilibrary.org/content/book/ 9789264167865-en.

OECD (2017). Land-use planning systems in the OECD. Country fact sheets. Paris: OECD Publishing. Retrieved from http://www.oecd.org/publications/land-use-planningsystems-in-the-oecd-9789264268579-en.htm.

Paryski, M., \& Pankratieva, I. (2012). A response to brussels' unexpected population growth in a context of existing urban fabric, or how to densify while keeping high quality of life. Presented at the 48th ISOCARP congress.

Pendall, R., Martin, J., \& Fulton, W. (2002). Holding the line: Urban containment in the United States. The Brooklings Instituion Center on Urban Metropolitan Policy. Retrieved from https://www.brookings.edu/wp-content/uploads/2016/06/ pendallfultoncontainment.pdf.

Peronato, G. (2014). Built density, solar potential and daylighting: Application of parametric studies and performance simulation tools in urban design. Lausanne: EPFL. Retrieved from https://infoscience.epfl.ch/record/201758.

Poradek, J. (1997). Putting the use back in metropolitan land-use planning: private enforcement of urban sprawl control laws. Minnesota Law Review, 81, 1343-1375.

Presland, A. (2016). Local planning authority green belt: England 2013/14. Department for Communities and Local Government. Retrieved from https://www.gov.uk/ government/uploads/system/uploads/attachment_data/file/551240/Green_Belt 
Statistics_England_2015-16.pdf.

Rafiee, R., Salman Mahiny, A., \& Khorasani, N. (2009). Assessment of changes in urban green spaces of Mashad city using satellite data. International Journal of Applied Earth Observation and Geoinformation, 11(6), 431-438. http://dx.doi.org/10.1016/j.jag. 2009.08.005.

Reiter, S., \& Marique, A.-F. (2012). Toward low energy cities: A case study of the urban area of Liege. Journal of Industrial Ecology, 16(6), 829-838. Retrieved from: https:// orbi.ulg.ac.be/handle/2268/123133.

Reiter, S. (2010). Assessing wind comfort in urban planning. Environment \& Planning B: Planning \& Design, 37(5), 857-873. Retrieved from: https://orbi.ulg.ac.be/handle/ 2268/17409.

de Roo, G. (2000). Environmental conflicts in compact cities: Complexity, decisionmaking, and policy approaches. Environment and Planning B: Planning and Design, 27(1), 151-162. http://dx.doi.org/10.1068/b2614.

Runkiewicz, L. (2009). Application of non-destructive testing methods to assess properties of construction materials in building diagnostics. Architecture Civil Engineering Environment, 2(2), 79-86.

Schmitt, P., \& Reardon, M. (2012). Sustainable urban growth through densification and regional governance. The Stockholm Case. Retrieved from http://www.diva-portal.org/ smash/record.jsf?pid = diva2:700338.

Seto, K. C., Fragkias, M., Güneralp, B., \& Reilly, M. K. (2011). A meta-analysis of global urban land expansion. PLos One, 6(8), e23777. http://dx.doi.org/10.1371/journal. pone.0023777.

Siedentop, S., Fina, S., \& Krehl, A. (2016). Greenbelts in Germany's regional plans-An effective growth management policy? Landscape and Urban Planning, 145, 71-82. http://dx.doi.org/10.1016/j.landurbplan.2015.09.002.

Stadt Köln (2011). Baulücken in Köln [City Adminstrational Website]. Retrieved July 13 2016, http://www.stadt-koeln.de/leben-in-koeln/planen-bauen/das-koelnerbaulueckenprogramm.

Steemers, K. (2003). Energy and the city: Density, buildings and transport. In in. Energy and Buildings, 35, 3-14.

Tichelmann, K., \& Groß, K. (2016). Wohnraumpotentiale durch Aufstockungen. Technische Universität Darmstadt. Retrieved from http://www.bak.de/berufspraxis/ bezahlbarer-wohnungsbau-fuer-alle/studie-tu-darmstadt-wohnraumpotentialedurch-aufstockung-langfassung.pdf.

United Nations (2015). Population division 2015. World Population prospects: The 2015 revision, key findings and advance tables (No. ESA/P/WP.241). Retrieved from https:// esa.un.org/unpd/wpp/publications/files/key_findings_wpp_2015.pdf.

United Nations. (2017, January 25). New Urban Agenda: Statement of financial implications (A/71/713). United Nations. Retrieved from http://www.un.org/en/ga/search/ view_doc.asp?symbol = A/RES/71/256.

van Heezik, Y., \& Adams, A. L. (2014). Vulnerability of native and exotic urban birds to housing densification and changing gardening and landscaping trends. Urban Ecosystems, 1-13. http://dx.doi.org/10.1007/s11252-014-0379-7.

Van de Voorde, S., Bertels, I., \& Wouters, I. (2015). post-war building materials: In housing in brussels 1945-1975. Vrije Universiteit Brussel: Graphius Group, Gent.

Vanneste, D., Thomas, I., \& Vanderstraeten, L. (2008). The spatial structure(s) of the Belgian housing stock. Journal of Housing and the Built Environment, 23, 173-198. http://dx.doi.org/10.1007/s10901-008-9111-3.

Vasili, Z. (2013). Urban containment policies in European regions. The case studies of Randstad and Greater London. The Netherlands: Nijmegen School of Management, Radboud University Nijmegen. Retrieved from http://gpm.ruhosting.nl/mt/2013MA-PL-19,ZacharoulaVasili.pdf.

Westerink, J., Haase, D., Bauer, A., Ravetz, J., Jarrige, F., \& Aalbers, C. B. E. M. (2012). Dealing with sustainability trade-offs of the compact city in peri-urban planning across European city regions. European Planning Studies, 21(4), 473-497.

Williams, K. (1997). The effectiveness of the UK planning in delivering sustainable development via urban intensificationOxford Brookes University Ph.D. Thesis.

Williams, K. (1998). Can planners implement urban intensification policies? Town and Country Planning, 67(10), 340-343.

Williams, K. (1999). Urban intensification policies in England: Problems and contradictions. Land Use Policy, 16(3), 167-178.

Williams, K., Burton, E., \& Jenks, M. (1996). Achieving the compact city through intensification. In M. Jenks, E. Burton, \& K. Williams (Eds.). The compact city: A sustainable urban form?. London: E \& FN Spon. 